\title{
Comparison of Individual and Synergistic Antimicrobial Activity of Common Spices against Certain Infectious Pathogen in Bangladesh
}

\author{
Sohana Parvin Chowdhury, Avijit Banik, Shahrin Akter Aurin, Sabera Saima* \\ Department of Microbiology, Primeasia University, Dhaka, Bangladesh \\ Email: ^saberasaima123@gmail.com
}

How to cite this paper: Chowdhury, S.P., Banik, A., Aurin, S.A. and Saima, S. (2019) Comparison of Individual and Synergistic Antimicrobial Activity of Common Spices against Certain Infectious Pathogen in Bangladesh. American Journal of Plant Sciences, 10, 1599-1611.

https://doi.org/10.4236/ajps.2019.109113

Received: August 8, 2019

Accepted: September 16, 2019

Published: September 19, 2019

Copyright $\odot 2019$ by author(s) and Scientific Research Publishing Inc. This work is licensed under the Creative Commons Attribution International License (CC BY 4.0).

http://creativecommons.org/licenses/by/4.0/

(c) (i) Open Access

\begin{abstract}
Aims: The aim of this undertaken investigation was designed to determine the comparative antimicrobial potential of ethanol extract of six commonly consumed spices such as Garlic (Allium satilyvum), Ginger (Zingiber officinale), Turmeric (Curcuma longa), Cinnamon (Cinnamomum zeylanicum), Cumin (Cuminum cyminum) and Black cumin (Nigella sativa). Method: This study includes, the efficacy of individual and synergistic effect of these extracts that was tested against bacteria by agar well-diffusion method employing $100 \mu \mathrm{L}$ spices-extract solution per well and was conducted in (Centre of Excellence Laboratory) Department of Microbiology, Primeasia University during November 2018 to April 2019. Minimum inhibitory concentration (MIC) was determined by the micro-broth dilution method and compared with commercial antibiotic discs such as Amoxicillin, Vancomycin, Erythromycin, Ceftriaxone, Chloramphenicol, and Ciprofloxacin. Result: According to the findings of the antibacterial assay, the ethanol extracts of the spices showed inhibitory activity against common infectious bacterial pathogens. Spice extracts have the most significant activity against B. cereus and E. coli was the least sensitive among the tested organisms. The ethanol extract had individual antibacterial activity with mean zone of inhibition $22 \pm 0.5$ and $20.08 \pm 0.58 \mathrm{~mm}$ and the synergistic effect of ethanol extract had a mean zone of inhibition $30 \pm 0.75$ and $28.25 \pm 0.9 \mathrm{~mm}$ against $B$. cereus and $V$. cholera, respectively, which is highly comparable to the commercial antibiotic, Ciprofloxacin $(25 \mathrm{~mm})$. Conclusion: The ethanol extract of indigenous spices was shown to be highly potential to be applied as an alternative of commercial drugs.
\end{abstract}




\section{Keywords}

Spice, Antibacterial Activity, Ethanol Extract, MIC, MBC, Synergistic Effect

\section{Introduction}

Since the last decades, commercially available antimicrobial drugs have been used to control microbial pathogenicity and other infectious diseases. Abundant and arbitrary use of antibiotics has developed multiple drug resistance (MDR) in many bacterial pathogens and it also created an ecological imbalance in the environment. Nowadays, increasing drug resistance is one of the main obstacles in proper treatment of infectious diseases and to the control of microbial pathogenicity at an alarming rate [1]. To explore new antimicrobial agents for the development of drug resistance in pathogens, the development of effective and nontoxic antimicrobial compounds from natural sources such as extracts of plants and herbs for food preservation have greatly increased [2] [3]. Antimicrobial activity of cinnamon oil against spores of anthrax bacilli was reported in 1830; it was the most ancient scientific document of the preservation potential of spices. In the last few years, massive studies have been conducted on the antimicrobial activities of plant extract against different microbe's strains. Use of different plants and spices based on antimicrobials can reduce or eliminate pathogenic microorganisms and increase the shelf life of food [4]. The natural products compared to commercial antibiotics are more effective with fewer side effects and it has become more demanding as natural antimicrobial preservatives and additives [5]. Spices are plant substances that are generally used to enrich flavor, aroma, and color which include leaves, flower, bud, seed, fruit, root, bark, berry, that is primarily used but spices have lots of medicinal value due to the antimicrobial activity exhibited by different bioactive compounds like alkaloids, flavonoids, isoflavonoids, tannins, cumarins, glycosides, terpenes and phenolic compounds [6]. Most of the Asian countries are rich in the heritage of the traditional medical system as well as in the biodiversity of the diverse range of spices for various treatment purposes [7]. In recent years, the use of natural substance especially spices has increased due to their biologically active status such as anti-oxidants, anti-fungal, anti-cancer agent and digestion facilitators and effects which provides body protection from various infections [8] [9] [10] [11]. Ethanol extract of six local Bangladeshi spices namely Cinnamon (Cinnamomum zeylanicum), Cumin (Cuminum cyminum), Turmeric (Curcuma longa), Garlic (Alliumsativum), Ginger (Zingiber officinale) and Black cumin (Nigella sativa) was used for this study. A number of studies have conducted different assessments to evaluate the synergistic or antagonistic effects of various spice extracts. The efficiency of the combination of extracts can be more promising against the microbial growth where individual action is less likely to be effective. Synergism often results from components of one spice supporting the other while improv- 
ing the total efficiency. Previously few reports were present on the synergistic/antagonistic effects of spice extracts especially on food-spoilage microorganisms [12] [13] [14]. A specific policy has been adopted by the World Health Organization (WHO) that primary health care sectors in developing countries throughout the world require more effective and efficient traditional medical practice [15].

The main purpose of the present study was to analyze the antimicrobial activity of the plant extracts of some selected spices against some food-borne isolates of Gram-positive and Gram-negative bacteria and also to determine their efficiency both as individually and synergistically.

\section{Materials and Methods}

\subsection{Spice Samples and Preparation of Their Extraction}

Six of the most common Bangladeshi spices such as Garlic (Allium sativum), Ginger (Zingiber officinale), Turmeric (Curcuma longa), Cinnamon (Cinnamomum zeylanicum), Cumin (Cuminum cyminum) and Black cumin (Nigella sativa) were procured from the local market in Mohakhali bazar, Dhaka, Bangladesh. The fresh bulb of garlic, fresh rhizomes of ginger, inner bark of cinnamon, fresh rhizomes of turmeric, fresh fruit of cumin and the fresh seed of Black cumin were collected in sterile zip lock bags (Table 1). The separable part (peel) of garlic, ginger, and turmeric was removed and the collected spices were cleaned and washed with fresh sterile water. After cleaning the spices were sliced and dried in a tray in a hot air oven at $40^{\circ} \mathrm{C}$ for 72 hours and dried spices were ground finely in a sterilized laboratory blender. For the preparation of extracts, $10 \mathrm{~g}$ of the prepared ground of dried spices were soaked in $90 \mathrm{ml}$ of $95 \%(\mathrm{w} / \mathrm{v})$ ethanol in sterilized Duran glass bottle and shaken at $100 \mathrm{rpm}$ in a reciprocal shaker (WIS-10, Wisecube, Germany) at room temperature for two days. The fraction of ethanol was separated by sterilized cheesecloth, then filtered through sterilized Whatman filter paper (No.01) and allowed the ethanol to evaporate at $40^{\circ} \mathrm{C}$ using a dry oven (ED53, Binder, Germany). After the evaporated extract was weighed, and dissolved in ethanol to a concentration of $200 \mathrm{mg} / \mathrm{ml}$, it was then stored at a refrigerator in a sterile vial for further experiments.

Table 1. Ethnobotanical description, part of plants and major components used in the antimicrobial study.

\begin{tabular}{cccccc}
\hline Name of Spice & Local Name & Scientific Name & Family & Part(s) Used & Major Components \\
\hline Garlic & Rohsun & Allium Sativum & Amaryllidaceae & Rhizome & Allicin, S-allylcysteine \\
Ginger & Ada & Zingiber officinale & Zingiberaecae & Bulb & Zingiberene, Gingerol \\
Turmeric & Holud & Curcuma longalim & Zingiberaceae & Rhizome & Curcuminoids \\
Cinnamon & Daarchini & Cinnamomum zeylanicum & Lauraceae & Bark & Trans-cinnamaldehyde and eugenol \\
Cumin & Jira & Cumin cyminum & Apiaceae & Fruit/seed & Thymoquinone \\
Black Cumin & Kalojira & Nigella sativa & Ranunculaceae & Fruit/seed & Cuminaldehyde \\
\hline
\end{tabular}




\subsection{Test Microorganisms}

Four Gram negative and two Gram positive bacterial strains were used in our study. Escherichia coli (ATCC 25922, Gram - ve), Vibrio cholerae (ATCC 14035, Gram - ve), Staphylococcus aureus (ATCC 6538, Gram + ve), Bacillus cereus (ATCC 14579, Gram + ve), Salmonella typhi (ATCC 14028, Gram - ve) and Pseudomonas spp. (Gram - ve) were tested for our study. Five ATCC strains and one isolated foodborne strain were collected from Department of Microbiology, Primeasia University, Dhaka. All freeze stored cultures were grown on nutrient broth medium by incubating at $37^{\circ} \mathrm{C}$ for $24 \mathrm{~h}$.

\subsection{Antimicrobial Agents, Media and Chemical}

The antibiotics used were Amoxicillin (AME-30 $\mu \mathrm{g}$ ), Vancomycin (VA-30 $\mu \mathrm{g}$ ), Erythromycin (E-15 $\mu \mathrm{g})$, Ceftriaxone (CRO-30 $\mu \mathrm{g})$, Chloramphenicol (C-30 $\mu \mathrm{g})$, and Ciprofloxacin (CIP-5 $\mu \mathrm{g}$ ) which were purchased from local laboratory market (Dhaka, Bangladesh). Nutrient Broth (NB) and Nutrient Agar (NA), Normal saline water, Mueller Hinton Broth (MHB), Mueller Hinton Agar (MHA) were used in our study. All chemicals used were of analytical-reagent grade.

\subsection{Screening for Antibacterial Activity}

In this study, the agar diffusion method was used for evaluation of the antibacterial activity of ethanol extracts of different spices. In this method, freeze stored nutrient broth cultures of bacterial strains were grown on nutrient agar plates and incubated overnight at $37^{\circ} \mathrm{C}$. One plate of each microorganism was taken and the colony was transferred into normal saline $(0.89 \%)$ under aseptic conditions. The density of each microbial suspension was adjusted to be equal to 0.5 Mcfanland units (approximately $10^{6} \mathrm{CFU} / \mathrm{ml}$ for bacteria) to use it as the inoculum for the agar well diffusion assay [16]. Selective bacterial strains were spread inoculated with a sterile cotton swab on the surface of sterile MHA plates so as to achieve a confluent growth. Following inoculation, agar well of $8 \mathrm{~mm}$ in diameter, $4 \mathrm{~mm}$ in depth and about $2 \mathrm{~cm}$ apart were punched in the MHA plate with a sterile cork borer. One hundred microliters $(100 \mu \mathrm{l})$ of the inoculum of each test organisms were poured into the labeled wells and kept aside for 3 hours before incubation at $37^{\circ} \mathrm{C}$ for $18-24$ hours as described in previous research [14] [17]. By using the disc diffusion method, the antibacterial activity of commercial drugs were determined [18]. Subsequent incubation under specified conditions, the results were recorded by evaluating the diameter of the zone of inhibition (ZOI) in $\mathrm{mm}$. The extracts were considered to be active, moderately active and highly active depending on their ability of clear zone parameter, respectively [19]. Each experiment was performed in triplicate and the mean values of the diameter of inhibition zone \pm standard deviations were also calculated [20].

\subsection{Determination of MIC and MBC}

Minimum inhibitory concentration (MIC) represents the lowest concentration 
of antimicrobial compound that can inhibit the visible growth of a microorganism after incubation overnight. The MIC values of extracts were determined based on a micro-broth dilution method by using 96 well microtiter plate [13]. In the first row of the plate, a volume of $100 \mu \mathrm{l}$ of test spices extract of ethanol (a stock concentration of $200 \mathrm{mg} / \mathrm{ml}$ of crude extract) was added. $100 \mu \mathrm{l}$ of nutrient broth was added to each well of the plate. Serial dilution of crude extracts were performed using a pipette such that every well had $100 \mu \mathrm{l}$ of serially descending concentration. Finally, $100 \mu \mathrm{l}$ of microbial suspension was added to each well to achieve a concentration of $5 \times 10^{6} \mathrm{CFU} / \mathrm{ml}$. One well of fresh extract and one well with tested bacteria was used as negative and positive control, respectively. Each plate was wrapped with a plastic cover lid to ensure that bacteria did not become dehydrated. The plates were prepared in triplicate and placed in an incubator at $37^{\circ} \mathrm{C}$ for overnight growth. The Minimum Bactericidal Concentration $(\mathrm{MBC})$ is the lowest concentration of antimicrobial agent that will kill any organism. In this study, the lowest concentration value of extracts that represented the absence of microbial growth on NA plates was recorded as the MBC [21].

\subsection{Synergistic Effect of Extracts}

Following the evaluation of the synergistic/combined effect of the various extracts by agar well diffusion method, their MIC and MBC was also tested where $1 / 2 \times$ MIC of the extracts were applied.

\subsection{Statistical Analysis}

The experiment was done in triplicate for each spice and was subjected to analysis of variance (ANOVA). Means and standard deviations were calculated, while $\mathrm{P}$-values were significant at the $\mathrm{P}<0.05$ level [22].

\section{Result}

In the current study, the antibacterial activity of each of the six spice extracts in ethanol solvent was examined. The mean diameters of the inhibition zone in millimeter of all tested spice extracts against six (4 Gram-positive, 2 Gram-negative) microbes were associated. Each tested spices of ethanol solvent for the antibacterial activity showed significant variation $(\mathrm{p}<0.05)$. Using Anova: single factor was conducted for determining statistical significance between different spice extract which revealed $\mathrm{P}$ value of 0.00015 , which is significant at the $\mathrm{P}<0.05$ level. Following preparation of spice extracts, $100 \mu \mathrm{l}$ of extracts were tested for their antibacterial activity using agar well diffusion method by the diameter of zone of inhibition.

From observing the result, Bacillus cereus (Gram-positive) was found to be more sensitive and E. coli (Gram-negative) was found to be more resistant among the six strains of bacteria used in this experiment. The antibacterial efficacy of spice extracts were found in the following order: Cinnamon $>$ Garlic $>$ 
Ginger $>$ Turmeric $>$ Cumin $>$ Black cumin. Among the entire tested organism, $B$. cereus showed the highest sensitivity against maximum spices, whereas other organisms showed heterogeneous degrees of sensitivity. Ethanolic extract of cinnamon exhibited maximum zone of inhibition (22 and $20.08 \mathrm{~mm}$ ) for B. cereus and $V$. cholera. Turmeric and cumin showed (15.5 and $12.58 \mathrm{~mm}$ ) and (16.67 and $16 \mathrm{~mm}$ ) ZOI for the similar organisms. However, Black cumin exhibited the lowest activity against three bacterial strains and other three strains showed no inhibitory activity. Garlic and ginger represented moderate inhibitory activity against all the selected bacterial species (Figure 1).

The antibacterial activity of spices was compared with six commercially available antibiotics using disc diffusion method as shown in Figure 2. Ciprofloxacin and chloramphenicol showed the highest activities of the zone of inhibition against all of the tested organisms. In the case of $B$. cereus, commercial disc chloramphenicol showed a zone of inhibition of $22 \mathrm{~mm}$ that was similar to that of the cinnamon extract. Furthermore, this study represents satisfying antibacterial activity compared to most commercial antibiotic drugs.

Less concentration of a drug is always preferable for the active result. In our present study, the synergistic effect of combination of every two spice was performed by agar well diffusion method to detect their zone of inhibition along with their MIC and MBC for all of the tested organisms. In a combined extract of cumin and cinnamon, a broader activity $(30.16 \mathrm{~mm} \mathrm{ZOI})$ against $B$. Cereus was observed, whereas they individually showed $22 \mathrm{~mm}$ and $16.67 \mathrm{~mm}$, respectively. Moreover, cinnamon extract combined with ginger, turmeric and garlic extract showed better effect against $B$. cereus than individual effect. Furthermore, individually, cumin, turmeric, garlic, and ginger exhibited (16 mm, $12.58 \mathrm{~mm}, 12.5 \mathrm{~mm}$ and $16.75 \mathrm{~mm}$ ) ZOI for $V$. cholerae, however, in combination with cinnamon extract, they showed an extensive zone of inhibition (26 $\mathrm{mm}, 28.17 \mathrm{~mm}, 27.56 \mathrm{~mm}$ and $28.25 \mathrm{~mm}$, respectively) for the similar organism.

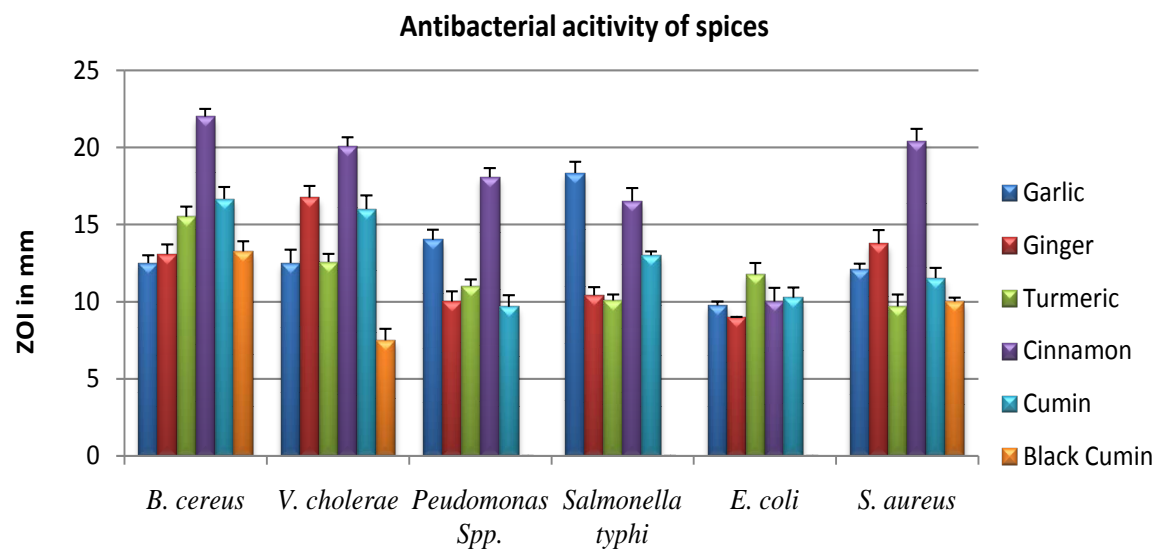

Figure 1. Antibacterial activity of spices extract against bacterial pathogens by agar well diffusion method. ${ }^{*}$ Values, including the diameter of the well $(8 \mathrm{~mm})$, mean of triplicates \pm SD. ${ }^{\star}$ Stranded deviation, within spices against six selected microorganisms, was found to be significant at $\mathrm{P}<0.05$. 
Antibacterial activity of commerical discs

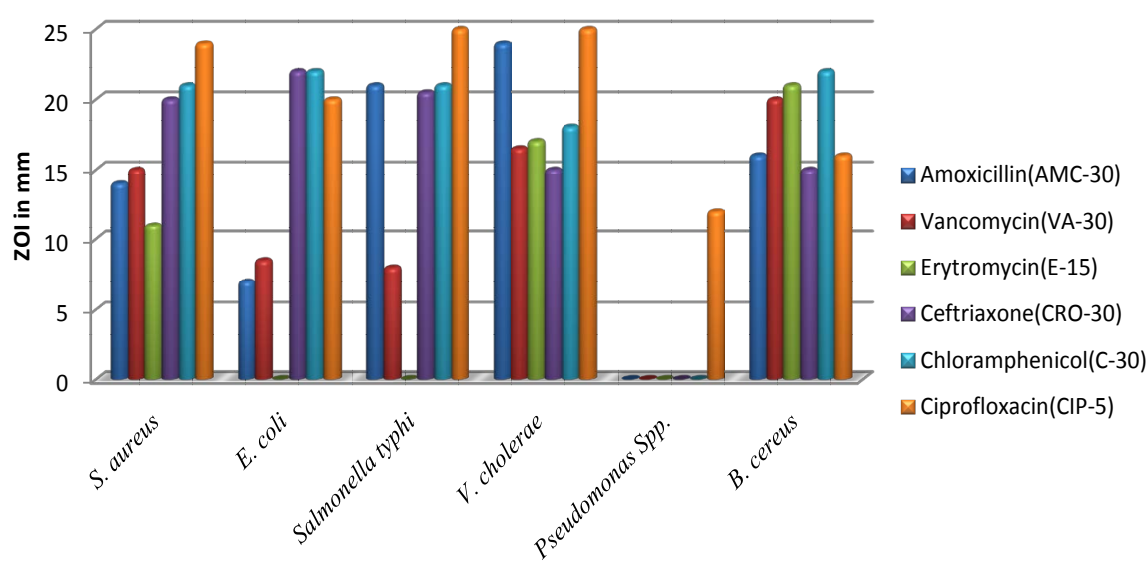

Figure 2. Antibacterial activity of commercial drugs against bacterial pathogens by agar well diffusion method.

All the tested spices showed the lowest ZOI both individually and synergistically for $E$. coli. (Table 2).

The MIC and MBC of spice extracts against tested bacterial strains were performed by broth dilution assay. Based on the concentration of the spice extracts, the pattern of inhibition of growth of the test organisms varied. The susceptibility of B. cereus, E. coli, S. aureus, V. cholerae, S. typhi, and Pseudomonas sp. to spice extracts were evaluated and the result was showed in (Figure 3). Cinnamon was the most effective spice with the MIC and MBC values ranged from 6.4 - $25.6 \mathrm{mg} / \mathrm{ml}$ and $25.6-51.2 \mathrm{mg} / \mathrm{ml}$ respectively. The lowest values of MIC and $\mathrm{MBC}$ of cinnamon were observed against $B$. cereus. In addition, the MIC and $\mathrm{MBC}$ values of garlic, ginger, turmeric, and cumin against $B$. cereus were ranged from $1.6-12.8 \mathrm{mg} / \mathrm{ml}$ and $3.2-25.6 \mathrm{mg} / \mathrm{ml}$ respectively. Among the other spices black cumin exhibited the highest MIC and MBC value $(25.6 \mathrm{mg} / \mathrm{ml}$ and 51.2 $\mathrm{mg} / \mathrm{ml}$ respectively), against $B$. cereus.

In the synergistic effect, most of the combine spice extracts showed convincing MIC and MBC against the tested organisms (Table 3). The synergistic effect of MIC and MBC was more effective than the individual effect against the tested strains. Combination of garlic-turmeric, garlic-ginger, garlic-cinnamon and also turmeric-cinnamon showed more efficiency against all of the tested bacteria.

\section{Discussion}

In this study, six spice extracts were tested to analyze the inhibitory effects of broad-spectrum activity against the tested microbes. Most of the tested spice extracts showed their antimicrobial effect against the tested microorganisms except black cumin which showed the lowest activity. In our study, ethanol extract of cinnamon showed $22 \mathrm{~mm}$ zone of inhibition (ZOI) for B. cereus whereas in previous reports of antimicrobial activity of ethanol extracts of cinnamon for similar organisms showed $18-20 \mathrm{~mm}$ ZOI in agar well diffusion method [14] [23] [24]. 
Table 2. Synergistic effect of all selected spices in combinations against tested bacterial strains.

\begin{tabular}{|c|c|c|c|c|c|c|}
\hline \multicolumn{7}{|c|}{ ZOI (Synergistic) } \\
\hline & B. cereus & V. cholerae & Pseudomonas spp. & Salmonella typhi & S. aureus & E. coli \\
\hline Garlic + Turmeric & $20.09 \pm 0.63$ & $21.17 \pm 0.77$ & $11.09 \pm 0.38$ & $10.17 \pm 0.77$ & $13.09 \pm 0.63$ & $10 \pm 0.5$ \\
\hline Ginger + Garlic & $15.17 \pm 0.77$ & $20.5 \pm 0.5$ & $12.5 \pm 0.25$ & $15 \pm 0.66$ & $10 \pm 0.5$ & $9 \pm 0.25$ \\
\hline Ginger + Cinnamon & $26.5 \pm 0.87$ & $28.25 \pm 0.9$ & $13.03 \pm 0.29$ & $16.92 \pm 0.52$ & $12.99 \pm 0.23$ & $9.09 \pm 0.63$ \\
\hline Ginger + Cumin & $13 \pm 0.44$ & $9.75 \pm 0.75$ & $11.3 \pm 0.46$ & $10.5 \pm 0.87$ & $10.98 \pm 0.47$ & $9.75 \pm 0.87$ \\
\hline Ginger + Black Cumin & $13.09 \pm 0.38$ & $9.75 \pm 0.66$ & $11.09 \pm 0.88$ & $10 \pm 1$ & $11.96 \pm 0.52$ & $10.96 \pm 0.25$ \\
\hline Turmeric + Ginger & $17 \pm 0.44$ & $22 \pm 0.25$ & $13 \pm 0.5$ & $10.59 \pm 0.38$ & $13 \pm 0.5$ & $14 \pm 0.5$ \\
\hline Turmeric + Cinnamon & $24.59 \pm 0.63$ & $28.17 \pm 0.38$ & $10 \pm 0.25$ & $14.92 \pm 0.63$ & $12 \pm 0.5$ & $0^{* * *}$ \\
\hline Turmeric + Cumin & $14.42 \pm 0.77$ & $14 \pm 0.5$ & $10.92 \pm 0.38$ & $8.98 \pm 0.47$ & $11.09 \pm 0.52$ & $10.92 \pm 0.38$ \\
\hline Turmeric + Black Cumin & $14.25 \pm 0.66$ & $12.92 \pm 0.72$ & $12.2 \pm 0.4$ & $10.33 \pm 0.88$ & $13.59 \pm 0.15$ & $12 \pm 0.5$ \\
\hline Garlic + Cinnamon & $25.5 \pm 1$ & $27.36 \pm 0.38$ & $9.75 \pm 0.66$ & $14.17 \pm 0.73$ & $9.5 \pm 0.5$ & $11 \pm 0.5$ \\
\hline Garlic + Cumin & $16.45 \pm 0.77$ & $11.5 \pm 0.87$ & $13.25 \pm 0.66$ & $12.5 \pm 0.5$ & $10 \pm 0.25$ & $8.67 \pm 0.38$ \\
\hline Garlic + Black Cumin & $15.34 \pm 1$ & $10 \pm 0.5$ & $10 \pm 0.5$ & $12.84 \pm 0.98$ & $12 \pm 0.34$ & $8.1 \pm 0.31$ \\
\hline Cinnamon + Cumin & $30.16 \pm 0.75$ & $26 \pm 0.25$ & $10.92 \pm 0.52$ & $10 \pm 1$ & $10 \pm 0.25$ & $12.75 \pm 0.25$ \\
\hline Cinnamon + Black Cumin & $14.11 \pm 0.66$ & $9.03 \pm 0.29$ & $10.97 \pm 0.46$ & $12.06 \pm 0.42$ & $11.33 \pm 0.33$ & $9.61 \pm 0.35$ \\
\hline Cumin + Black Cumin & $17.5 \pm 1$ & $14.09 \pm 0.38$ & $0^{* * *}$ & $0^{* * *}$ & $0^{* * *}$ & $13 \pm 0.5$ \\
\hline
\end{tabular}

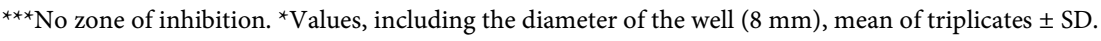

Table 3. Synergistic effect of MIC and MBC spices combinations against tested bacterial strains.

\begin{tabular}{|c|c|c|c|c|c|c|c|c|c|c|c|c|}
\hline \multicolumn{13}{|c|}{$\mathrm{MIC} / \mathrm{MBC}$ (Synergistic) of $\mathrm{mg} / \mathrm{ml}$ Concentration } \\
\hline & \multicolumn{2}{|c|}{ B. cereus } & \multicolumn{2}{|c|}{ V. cholerae } & \multicolumn{2}{|c|}{ Pseudomonas spp. } & \multicolumn{2}{|c|}{ Salmonella typhi } & \multicolumn{2}{|c|}{ S. aureus } & \multicolumn{2}{|c|}{ E. coli } \\
\hline & MIC & $\mathrm{MBC}$ & MIC & $\mathrm{MBC}$ & MIC & $\mathrm{MBC}$ & MIC & $\mathrm{MBC}$ & MIC & MBC & MIC & MBC \\
\hline Garlic + Turmeric & 0.8 & 1.6 & 1.6 & 3.2 & 3.2 & 12.8 & 3.2 & 6.4 & 0 & 0 & 51.2 & 0 \\
\hline Ginger + Garlic & 1.6 & 3.2 & 3.2 & 6.4 & 1.6 & 6.4 & 12.8 & 25.6 & 25.6 & 51.2 & 25.6 & 51.2 \\
\hline Ginger + Cinnamon & 3.2 & 6.4 & 0.8 & 1.6 & 25.6 & 102.4 & 25.6 & 51.2 & 25.6 & 51.2 & 12.8 & 25.6 \\
\hline Ginger + Cumin & 25.6 & 51.2 & 25.6 & 51.2 & 12.8 & 51.2 & 25.6 & 51.2 & 25.6 & 51.2 & 25.6 & 51.2 \\
\hline Ginger + Black Cumin & 25.6 & 51.2 & 0 & 0 & 25.6 & 102.4 & 0 & 0 & 51.2 & 0 & 25.6 & 51.2 \\
\hline Turmeric + Ginger & 6.4 & 12.8 & 12.8 & 25.6 & 25.6 & 102.4 & 25.6 & 51.2 & 25.6 & 51.2 & 51.2 & 0 \\
\hline Turmeric + Cinnamon & 0.8 & 1.6 & 0.8 & 1.6 & 25.6 & 102.4 & 6.4 & 12.8 & 51.2 & 0 & 51.2 & 0 \\
\hline Turmeric + Cumin & 25.6 & 51.2 & 25.6 & 51.2 & 12.8 & 51.2 & 3.2 & 6.4 & 25.6 & 51.2 & 25.6 & 51.2 \\
\hline Turmeric + Black Cumin & 25.6 & 51.2 & 25.6 & 51.2 & 25.6 & 102.4 & 25.6 & 51.2 & 25.6 & 51.2 & 0 & 0 \\
\hline Garlic + Cinnamon & 1.6 & 3.2 & 0.8 & 1.6 & 1.6 & 6.4 & 12.8 & 25.6 & 0 & 0 & 51.2 & 0 \\
\hline Garlic + Cumin & 1.6 & 3.2 & 25.6 & 51.2 & 1.6 & 6.4 & 25.6 & 51.2 & 0 & 0 & 25.6 & 51.2 \\
\hline Garlic + Black Cumin & 3.2 & 6.4 & 0 & 0 & 1.6 & 6.4 & 0 & 0 & 25.6 & 51.2 & 0 & 0 \\
\hline Cinnamon + Cumin & 1.6 & 3.2 & 25.6 & 51.2 & 12.8 & 51.2 & 12.8 & 25.6 & 51.2 & 0 & 25.6 & 51.2 \\
\hline Cinnamon + Black Cumin & 3.2 & 6.4 & 0 & 0 & 25.6 & 102.4 & 25.6 & 51.2 & 51.2 & 0 & 0 & 0 \\
\hline Cumin + Black Cumin & 6.4 & 12.8 & 0 & 0 & 0.8 & 3.2 & 25.6 & 51.2 & 25.6 & 51.2 & 25.6 & 51.2 \\
\hline
\end{tabular}




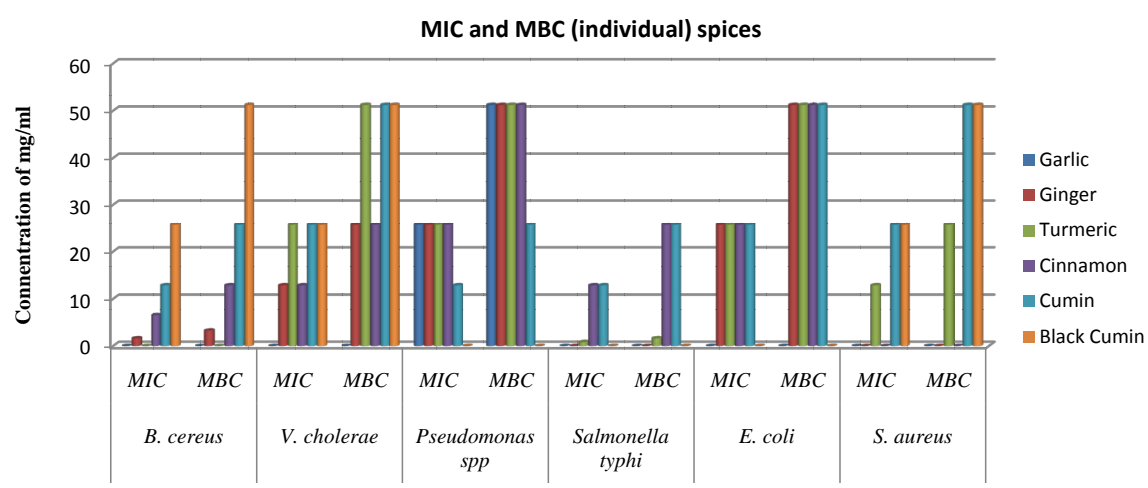

Figure 3. Individual effect of MIC and MBC of spices against tested bacterial strains.

S. aureus, E. coli, Pseudomonas and S. typhi showed a significant sensitivity to the antimicrobial effect of cinnamon as much as similar to corresponding data showed in previous research [25] [26]. Individual extract of garlic and ginger showed moderate activity against E. coli $(9.75 \pm 0.25 \mathrm{~mm} \mathrm{ZOI,} 9 \pm 0 \mathrm{~mm}$ ZOI$)$, S. aureus $(12.08 \pm 0.38 \mathrm{~mm}$ ZOI, $13.75 \pm 0.9 \mathrm{~mm} \mathrm{ZOI})$ and Salmonella typhi (18.34 $\pm 0.72 \mathrm{~mm}$ ZOI) that resembled previous data of the researcher [13] [27]. In the synergistic combination, cinnamon showed the highest activity when combined with cumin, ginger, turmeric and garlic spices, respectively, against $B$. cereus and $V$. cholera. In our study, Black cumin ethanol extract did not show any activity against Pseudomonas spp., Salmonella typhi and E. coli in agar well diffusion method unlike previous articles [28] [29].

The spice extracts showed more sensitivity in case of ZOI and MIC values against Gram-positive bacteria than Gram-negative bacteria [30]. Most of the MIC values of synergistic extracts of spices were reduced by half of the MIC values of individual extracts. However, antimicrobial activities of combined extract were more effective since antimicrobial properties of herbs and spices not only depend on their chemical compositions but also on their lipophilic properties, water solubility and various compounds that may have contributed to the observed additive effects [13] [31]. The synergistic extract activities represented wide antibacterial activity in comparison with commercial antibiotics that were tested.

Synthetic and semi-synthetic drugs have been used for antibacterial, antiparasitic and antifungal activities. But in recent years, microorganisms showed more resistance pattern against the antibiotics that are usually used. In our study, Pseudomonas sp Showed $100 \%$ resistance against amoxicillin, vancomycin, erythromycin, ceftriaxone, and chloramphenicol. In previous researches, Pseudomonas spp. was also found in clinical and food isolates and their antibiotic results were more similar to our antibiotics resistance result [32] [33]. The commercial drugs also have side effects on digestive system and some may also show allergic reaction. However, only ciprofloxacin showed the intermediate result $(12 \mathrm{~mm})$ for Pseudomonas spp. whereas, the cinnamon extract showed the highest activity $(18.08 \pm 0.58 \mathrm{~mm})$ against the same strains in our study. E. coli and Salmonella isolated from meat samples showed resistance to erythromycin $(85.71 \%$ and $100 \%$ ) in the previous report [34] [35]. In our study, erythromycin showed 100\% 
resistance and vancomycin also presented the lowest sensitivity against $E$. coli and $S$. typhi isolates. The activities of amoxicillin, ceftriaxone, and chloramphenicol $(21 \mathrm{~mm}, 20.5 \mathrm{~mm}$, and $21 \mathrm{~mm})$ were close to the activity to garlic against $S$. typhi in our study. In the synergistic activities, a combination of ginger and cinnamon, turmeric and cinnamon, garlic and cinnamon showed the highest activities $(28.25 \pm 0.9,28.17 \pm 0.38,27.36 \pm 0.38 \mathrm{~mm}$ ZOI $)$ against $V$. cholerae but among the commercial antibiotics, ciprofloxacin showed the highest activity of $25 \mathrm{~mm}$ ZOI for the same bacterial strain. Therefore, combinations of spices and other natural antimicrobial agents may increase food shelf life by destroying food spoilage organisms and can be used as alternative drugs to treat mild sickness instead of using commercial drugs. Mostly, the natural bioactive compound has shown to affect the structure and integrity, permeability or functionality of cytoplasmic membrane [36] [37] [38] [39], and the efflux system of target bacteria. The antimicrobial activity of alternative plant bioactive components has shown to activate immune cells and enhance the growth of beneficial gut flora [40]. In fact, the efficacy of bioactive compound is regulated by the target site and structure of bacterial cells as well as environmental factors like redox potential, moisture content, hydrophilicity, temperature, $\mathrm{pH}$, acidity and availability of nutrients of target bacteria [36]. However the concentration of active bactericidal components of spices is a matter of concern in case of practical application of natural drug formulation.

Extravagant use of antibiotics in treatment and chemical antimicrobial preservatives in food preservation are the major causes of emerging drug resistance day by day. Last five decades of misuse or uncontrolled use of antimicrobials has led to multi-drug resistant microorganisms and ecological imbalance that is alarming for the very near future.

\section{Conclusion}

In concluding, the present studies demonstrate that spice extracts have a promising result for antibacterial activity. Interestingly, some combinations of spices induced the inhibitory activity of specific microorganisms. In recent past times, the researchers kept an eye on the antimicrobial properties of spices and tried to know about the defined mechanism of those spices, their effect on individual pathogens and also synergistic effect when used in combinations with other spices or antibiotics. Hence, continuous screenings of new antimicrobial agents and at the same time detailed studies are required to overcome the drug resistance issue.

\section{Authors' Contributions}

This work was carried out in collaboration between all authors. Authors $A B$ and SS designed the study. Author SPC, AB, and SAA managed the experimental process and analyses of the raw data. Authors $\mathrm{AB}$ and $\mathrm{SS}$ wrote the protocol and the first draft of the manuscript. Author SAA and SPC managed the literature searches. All authors read and approved the final manuscript. 


\section{Conflicts of Interest}

The authors declare no conflicts of interest regarding the publication of this paper.

\section{References}

[1] Fu, Y.J., Zu, Y.G., Chen, L.Y., Shi, X.H.G., Wang, Z., Sun, S. and Efferth, T. (2007) Antimicrobial Activity of Clove and Rosemary Essential Oils Alone and in Combination. Phytotherapy Research, 21, 989-999. https://doi.org/10.1002/ptr.2179

[2] Erdogrul, O.T. (2002) Antibacterial Activities of Some Plant Extracts Used in Folk Medicine. Pharmaceutical Biology, 40, 269-273.

https://doi.org/10.1076/phbi.40.4.269.8474

[3] Shan, B., Cai, Y.Z., Brook, J.D. and Corke, H. (2007) The in Vitro Antibacterial Activity of Dietary Spice and Medicinal Herb Extracts. International Journal of Food Microbiology, 117, 112-119. https://doi.org/10.1016/j.ijfoodmicro.2007.03.003

[4] Tajkarimi, M.M., Ibrahim, S.A. and Cliver, D.O. (2010) Antimicrobial Herb and Spice Compounds in Food. Food Control, 21, 1199-1218. https://doi.org/10.1016/j.foodcont.2010.02.003

[5] Akarpat, A., Tuthan, S. and Ustun, N.S. (2008) Effects of Hot Water Extracts from Myrtle, Rosemary, Nettle and Lemon Balm Leaves on Lipid Oxidation and Color of Beef Patties during Frozen Storage. Journal of Food Processing and Preservation, 32, 117-132. https://doi.org/10.1111/j.1745-4549.2007.00169.x

[6] Maharjan, D., Singh, A., Lekhak, B., Basnyat, S. and Gautam, L. (2012) Study on Antibacterial Activity of Common Spices. Nepal Journal of Science and Technology, 12, 312-317. https://doi.org/10.3126/njst.v12i0.6518

[7] Pei, S.-J. (2001) Ethnobotanical Approaches of Traditional Medicine Studies: Some Experiences from Asia. Pharmaceutical Biology, 39, 74-79.

https://doi.org/10.1076/phbi.39.s1.74.0005

[8] Suvarna, R., Bhat, S.S. and Hegde, K.S. (2014) Antibacterial Activity of Turmeric against Enterococcus faecalis an in Vitro Study. International Journal of Current Microbiology and Applied Sciences, 3, 498-504.

[9] Berrington, D. and Lall, N. (2012) Anticancer Activity of Certain Herbs and Spices on the Cervical Epithelial Carcinoma (HeLa) Cell Line. Evidence-Based Complementary and Alternative Medicine, 2012, Article ID: 564927. https://doi.org/10.1155/2012/564927

[10] Ichwan, S.J., Al-Ani, I.M., Bilal, H.G., Suriyah, W.H., Taher, M. and Ikeda, M.A. (2014) Apoptotic Activities of Thymoquinone, an Active Ingredient of Black Seed (Nigella sativa), in Cervical Cancer Cell Lines. The Chinese Journal of Physiology, 57, 249-255. https://doi.org/10.4077/CJP.2014.BAB190

[11] Mehta, H.J., Patel, V. and Sadikot, R.T. (2014) Curcumin and Lung Cancer-A Review. Targeted Oncology, 9, 295-310. https://doi.org/10.1007/s11523-014-0321-1

[12] Kota, C.S. and Paladi, S. (2013) Evaluation of Antibacterial Activity of Syzygium aromaticum, Laurus Nobilis and Cuminum cyminum Extracts and Their Combination. International Journal of Pharmaceutical Sciences and Research, 4, 4745-4748. https://doi.org/10.13040/IJPSR.0975-8232.4(12).4745-48

[13] Baljeet, S.Y., Simmy, G., Ritika, Y. and Roshanlal, Y. (2015) Antimicrobial Activity of Individual and Combined Extracts of Selected Spices against Some Pathogenic and Food Spoilage Microorganisms. International Food Research Journal, 22, 2594-2600. 
[14] Banik, A., Abony, M., Zerin, T. and Datta, S. (2018) Antibacterial Activity of Allium sativum, Syzygium aromaticum, and Cinnamomum zeylanicum against Food Borne Pathogens in Vitro. IOSR Journal of Pharmacy and Biological Sciences, 13, 68-73.

[15] Datta, A., Ghoshdastidar, A. and Singh, M. (2011) Antimicrobial Property of Piper betel Leaf against Clinical Isolates of Bacteria. International Journal of Pharmaceutical Sciences and Research, 2, 104-109.

[16] Yadav, M., Yadav, A., Kumar, S., Sharma, D. and Yadav, J.P. (2014) Evaluation of in Vitro Antibacterial Potential of Endophytic Fungi Isolated from Eugenia Jambolana Lam. International Journal of Pharmacy and Pharmaceutical Sciences, 6, 208-211.

[17] Nahor, U. and Ahmed, Z. (2012) Antibacterial Activity of Phyllanthus emblica and Allium sativum: Comparative Analysis of Antibacterial Action of Crude and Ethanolic Extract of These Natural Plant Products. IOSR Journal of Pharmacy and Biological Sciences, 4, 21-26. https://doi.org/10.9790/3008-0432126

[18] Bauer, A.W., Kirby, W.M.M., Sherris, J.C. and Turck, M.D. (1966) Antibiotic Susceptibility Testing by Standardized Single Disk Method. American Journal of Clinical Pathology, 45, 493-496. https://doi.org/10.1093/ajcp/45.4_ts.493

[19] Arora, D.S. and Kaur, J. (1999) Antibacterial Activity of Spices. International Journal of Antibacterial Agents, 12, 257-262. https://doi.org/10.1016/S0924-8579(99)00074-6

[20] Aneja, K.R., Joshi, R. and Sharma, C. (2010) Potency of Barleria prionitis L. Bark Extracts against Oral Diseases Causing Strains of Bacteria and Fungi of Clinical Origin. New York Science Journal, 3, 5-12.

[21] Ncube, N.S., Afolayan, A.J. and Okoh, A.I. (2008) Assessment Techniques of Antimicrobial Properties of Natural Compounds of Plant Origin: Current Methods and Future Trends. African Journal of Biotechnology, 7, 1797-1806. https://doi.org/10.5897/AJB07.613

[22] Steel, R.O.D. and Torrie, J.H. (1980) Principles and Procedures of Statistics. A Biometrical Approach. McGraw-Hill, New York, 633 p.

[23] Dhiman, R., Aggarwal, N.K. and Kaur, M. (2015) Comparative Evaluation of Antimicrobial Activities of Commonly Used Indian Spices against Microbes Associated with Juices. Research Journal of Microbiology, 10, 170-180.

https://doi.org/10.3923/jm.2015.170.180

https://scialert.net/abstract/?doi=jm.2015.170.180

[24] Tail, A.A. and El-Tras, W.F. (2009) Possibility of Fighting Food Borne Bacteria by Egyptian Folk Medicinal Herbs and Spices Extracts. Journal of the Egyptian Public Health Association, 84, 21-32.

[25] Gupta, C., Garg, A.P., Uniyal, R.C. and Kumari, A. (2008) Comparative Analysis of the Antibacterial Activity of Cinnamon Oil and Cinnamon Extraction Some Food-Borne Microbes. African Journal of Microbiology Research, 2, 247-251.

[26] Shete, H.G. and Chitanand, M.P. (2014) Antimicrobial Activity of Some Commonly Used Indian Spices. International Journal of Current Microbiology and Applied Sciences, 3, 765-770.

[27] Gull, I., Saeed, M., Shaukat, H., MAslam, S., Samra, Z.Q. and Athar, A.M. (2012) Inhibitory Effect of Allium sativum and Zingiber officinale Extracts on Clinically Important Drug Resistant Pathogenic Bacteria. Annals of Clinical Microbiology and Antimicrobials, 11, 8. https://doi.org/10.1186/1476-0711-11-8

[28] Rahman, M., Wadud, M., Islam, T., Hussain, M., Bristy, E.M. and Tuhin, A. (2018) Evaluation of Antibacterial Activity of Piper Betel Leaves and Nigella sativa Seeds against Multidrug Resistant Food and Water Borne Pathogenic Bacteria: An in $\mathrm{Vi}$ 
tro Study Model. Microbiology Research Journal International, 22, 1-11. https://doi.org/10.9734/MRJI/2017/37796

[29] Zuridah, H., Fairuz, A.R.M., Zakri, A.H.Z. and Rahim, M.N.A. (2008) In Vitro Antibacterial Activity of Nigella sativa against Staphylococcus aureus, Pseudomonas aeruginosa, Klebsiella pneumoniae, Escherichia coli and Bacillus cereus. Asian Journal of Plant Sciences, 7, 331-333. https://doi.org/10.3923/ajps.2008.331.333

https://scialert.net/abstract/?doi=ajps.2008.331.333

[30] Weerakkody, N.S., Caffin, N., Turner, M.S. and Dykes, G.A. (2010) In Vitro Antimicrobial Activity of Less-Utilized Spice and Herb Extracts against Selected Food Borne Bacteria. Food Control, 21, 1408-1414.

https://doi.org/10.1016/j.foodcont.2010.04.014

[31] Gutierrez, J., Barry-Ryan, C. and Bourke, P. (2009) Antimicrobial Activity of Plant Essential Oils Using Food Model Media: Efficacy, Synergistic Potential and Interactions with Food Components. Food Microbiology, 26, 142-150. https://doi.org/10.1016/j.fm.2008.10.008

[32] Nwinyi, O.C., Obehi, E., Tomilola, A., Oniha, M.I. and Bunmi, O. (2017) Antibiotic Susceptibility Patterns of Bacteria Species Isolated from Ice-Cream Vended in Ota and Lagos Metropolis. Research Journal of Microbiology, 12, 50-57.

https://doi.org/10.3923/jm.2017.50.57 https://scialert.net/abstract/?doi=jm.2017.50.57

[33] Bhuiya, M., Sarkar, M.K.I., Sohag, M.H., Ali, H., Roy, C.K., Akther, L. and Sarker, A.F. (2018) Enumerating Antibiotic Susceptibility Patterns of Pseudomonas aeruginosa Isolated from Different Sources in Dhaka City. The Open Microbiology Journal, 12, 172-180. https://doi.org/10.2174/1874285801812010172

[34] Rahman, M.A., Rahman, A.K.M.A., Islam, M.A. and Alam, M.M. (2017) Antimicrobial Resistance of Escherichia coli Isolated from Milk, Beef and Chicken Meat in Bangladesh. Bangladesh Journal of Veterinary Medicine, 15, 141-146. https://doi.org/10.3329/bjvm.v15i2.35525

[35] Rahman, M.A., Rahman, A.K.M.A., Islam, M.A. and Alam, M.M. (2018) Detection of Multi-Drug Resistant Salmonella from Milk and Meat in Bangladesh. Bangladesh Journal of Veterinary Medicine, 16, 115-120. https://doi.org/10.3329/bjvm.v16i1.37388

[36] Radulovic, N.S., Blagojevic, P.D., Stojanovic-Radic, Z.Z. and Stojanovic, N.M. (2013) Antimicrobial Plant Metabolites: Structural Diversity and Mechanism of Action. Current Medicinal Chemistry, 20, 932. https://doi.org/10.2174/0929867311320070008

[37] Savoia, D. (2012) Plant-Derived Antimicrobial Compounds: Alternatives to Antibiotics. Future Microbiology, 7, 979-990. https://doi.org/10.2217/fmb.12.68

[38] Saleem, M., Nazir, M., Ali, M.S., Hussain, H., Lee, Y.S., Riaz, N. and Jabbar, A. (2010) Antimicrobial Natural Products: An Update on Future Antibiotic Drug Candidates. Natural Product Reports, 27, 238-254. https://doi.org/10.1039/B916096E

[39] Burt, S. (2004) Essential Oils: Their Antibacterial Properties and Potential Applications in Foods-A Review. International Journal of Food Microbiology, 94, 223-253. https://doi.org/10.1016/j.ijfoodmicro.2004.03.022

[40] Suresh, G., Das, R.K., KaurBrar, S., Rouissi, T., Avalos Ramirez, A., Chorfi, Y. and Godbout, S. (2018) Alternatives to Antibiotics in Poultry Feed: Molecular Perspectives. Critical Reviews in Microbiology, 44, 318-335. https://doi.org/10.1080/1040841X.2017.1373062 